\title{
Spore diversity among species of Blechnaceae in the Atlantic Forest
}

\author{
Dilma Melo da Silva ${ }^{1}$, Lana da Silva Sylvestre ${ }^{2}$ (D), Cláudia Barbieri Ferreira Mendonça ${ }^{3}$ (1) and Vania \\ Gonçalves-Esteves ${ }^{3 *}$ (1)
}

Received: September 23, 2018

Accepted: March 8, 2019

\begin{abstract}
The palynological diversity of Blechnaceae in the Atlantic Forest was investigated. While the monophyletic family belongs to the group of leptosporangiate ferns, a new classification proposed by recent phylogenetic study reorganizes the family and adds new genera. To expand palynological knowledge of the group, the spore morphology of 23 species and a hybrid, distributed among 10 genera, was described. Material from herbarium collections were submitted to acetolysis and mounted on slides, with subsequent statistical analysis of spore measurements. Photomicrographs of the material were taken under both light and scanning electron microscopy. Perine ornamentation varied among psilate, rugulate and scabrate; granules and gemmae were present along with thin, smooth cristae. Species of Blechnum and Austroblechnum exhibited the greatest diversity. The attributes of the spores obtained here were able to differentiate the analyzed species, although the spore morphology of some taxa was found to be very similar. Multivariate analysis assessed the relevance of quantitative data for differentiating the taxa.
\end{abstract}

Keywords: Austroblechnum, Blechnum, spore, multivariate analysis, palynology

\section{Introduction}

Blechnaceae is a monophyletic family of leptosporangiate ferns (Smith et al. 2006; Rothfels et al. 2012; Gasper et al. 2017), comprising 24 genera and ca. 265 species (PPG I 2016). It has a subcosmopolitan distribution with a predominance of genera and species in the Southern Hemisphere, with two centers of diversity and endemism: one in the Neotropics and one in Australia/Oceania (Dittrich et al. 2007). In Brazil the family is represented by 10 genera and 32 species (plus two natural hybrids), with the Southeast Region of the country being home to the largest number of taxa and eight endemic species (Blechnaceae in Flora do Brasil 2020). The Atlantic Forest is the phytogeographic domain with the greatest number of recognized taxa for the group with 24 species and two hybrids, followed by the Amazon and the
Cerrado: Austroblechnum (six spp.), Blechnum (10 spp.), Cranfillia (two spp.), Lomaria, Lomaridium, Lomariocycas, Neoblechnum (one sp. each), Parablechnum (three spp.), Sapichlaena and Telmatoblechnum (one sp. each) (Blechnaceae in Flora do Brasil 2020).

Although the diversity of the family was studied 70 years ago, more recent studies have addressed infrageneric relationships, which have resulted in the proposal of new classifications. Most recently, Gasper et al. (2017) re-organized Blechnaceae in 2016 (Gasper et al. 2016), using the results of a molecular phylogenetic analysis, and proposed a new classification for the family.

Spores of Blechnaceae were initially studied by Erdtman \& Sorsa (1971), who analyzed ca. 30 species from the Australia/Oceania region. Other studies have since made additional contributions to the knowledge of the spores of the family, including Lloyd (1976), Morbelli (1974;

1 Departamento de Biologia Vegetal, Universidade do Estado do Rio de Janeiro, 20550-900, Rio de Janeiro, RJ, Brazil

2 Departamento de Botânica, Universidade Federal do Rio de Janeiro, 21941-902, Rio de Janeiro, RJ, Brazil

3 Departamento de Botânica, Museu Nacional Quinta da Boa Vista, Universidade Federal do Rio de Janeiro, 20940-040, Rio de Janeiro, RJ, Brazil

* Corresponding author: esteves.vr@gmail.com 
1976), Giacosa et al. (2009), Morbelli et al. (2009), Tryon \& Tryon (1982), Tryon \& Lugardon (1990), Passarelli (2007), Passarelli et al. (2010) and Moran et al. (2018).

Research on the spores of Blechnaceae has been almost non-existent in Brazil. Sylvestre (1995) analyzed and described spores of the family Polypodiaceae s.l. of the Itatiaia Plateau in the state of Rio de Janeiro, including five species of Blechnum. Coelho \& Esteves (2008) analyzed seven species of Blechnaceae from the State Park of the Fontes do Ipiranga in the state of São Paulo, and highlighted the existence of a laminar surface on the spores, which they felt would be possessed by the entire family and thus differentiate it from all other ferns.

The present study aimed to describe the spore morphology of taxa of the family Blechnaceae of the Atlantic Forest using qualitative and quantitative data, and to perform a palynological analysis of the different genera of the family.

\section{Material and methods}

Twenty-two species and one hybrid of 10 genera, representing most of the taxa found in the Atlantic Forest, were analyzed. Spores were extracted from specimens of the following herbaria: BHCB, HB, HRJ, R and RB (acronyms in accordance with Index Herbariorum, Thiers 2018) (List S1 in supplementary material).

For light microscopy (LM), spore material was acetolysed following Erdtman (1952), with modifications by Melhem et al. (2003), and measured and photographed within seven days (Salgado-Labouriau 1973). Spores that demonstrated fragility to this acetolysis method (Erdtman 1952), were prepared via $40 \%$ lactic acetolysis (Raynal \& Raynal 1971), and measured and photomicrographed within three days (Wanderley \& Melhem 1991). For better visualization of the ornamentation of the perine, some spores of some species were treated following Wodehouse (1935).

Twenty-five spores were measured for polar diameter (PD) and equatorial diameter (ED) in equatorial view. Ten spores were measured for largest diameter (LD), smallest diameter (SD) and laesure length in polar view and for exine and perine thickness in equatorial view. All spores were randomly chosen from standard material on a minimum of three different slides. Measurements of standard and comparative material followed well established methods (Souza et al. 2016; Sousa et al.2017; Almeida et al. 2018).

Descriptive terminology followed Punt et al. (2007) for spore size and shape, laesure, and exine and perine ornamentation. Photomicrographs under LM were taken with a Canon Power Shot G6 digital camera coupled to a Zeiss Axiostar Plus microscope with a 100X objective. Electromicrographs were obtained using a ZEISS DS M960 scanning electron microscope (SEM). All slides used in the study were deposited in the Palinoteca of the Palinology Álvaro Xavier Moreira Laboratory, of the Department of
Botany of the National Museum, Universidade Federal do Rio de Janeiro.

Statistical analyses were performed and the arithmetic mean $(\mathrm{x})$, the standard deviation of the mean (sx), and the $95 \%$ confidence interval (CI) were calculated for measured variables.

Exploratory data analysis was performed using PCORD version 5.31 (McCune \& Mefford 2011). Attributes of the spores of the analyzed species were organized in a data matrix with a total of eight variables. For better organization of graphics, names of species were abbreviated with the first three letters of the specific epithets, with the exception of the hybrid $B . \times$ caudatum, while spore attributes were abbreviated by their initials. Variables included in the multivariate analyses were: PD (polar diameter), ED (equatorial diameter), LD (largest diameter), SD (smallest diameter) CiC (laesure), sexine (sex), nexine (nex). The matrix used for multivariate analyses (PCA and cluster analysis) was transformed by 0.5 -square root in order to standardize the data.

Principal component analysis (PCA) was carried out to order the variables and determine if spore attributes grouped the species. The variance-covariance matrix (varcov) was obtained from the means of the morphometric data of the palynological analysis, and coordinated in a biplot plot based on Euclidean distance. The results were presented in a two-dimensional chart with the first and second principal components (axes). The values of the vectors of each axis and total cumulative variance were presented in tables.

Cluster analysis (Cluster-AHC) was performed to classify species into groups that share (similarity) pollen variables. Two aspects were considered in relation to the groups formed and the set of analyzed variables: the percentage of information needed to form the groups, and the final number of groups formed. The results are presented as a dendogram constructed using Euclidean distance (Caccavari et al. 2008) and Ward's linkage method.

\section{Results}

\section{Size, polarity and symmetry}

The studied spores (Figs. 1-5) were medium to large in size (Tabs. 1-3), with the smallest diameter in equatorial view being for Blechnum asplenioides $(49.7 \mu \mathrm{m})$ and the largest for Salpichlaena volubilis $(93.3 \mu \mathrm{m})$. The spores wee found to be heteropolar, bilaterally symmetrical, ellipsoidal in polar view (Figs. 1I, O, 2G, 3A, 4G), and plane-convex in equatorial view (Figs. 1F, 2D, J, 3B, E, O, 4D, 5A).

\section{Laesure}

Thelaesure was monolete and linear for all taxa (Figs. 1E, O, 2A, D, G), except for A. andinum, which has a slightly sinuous scar (Fig. 1A). The laesure lacks a margin (i.e., without 

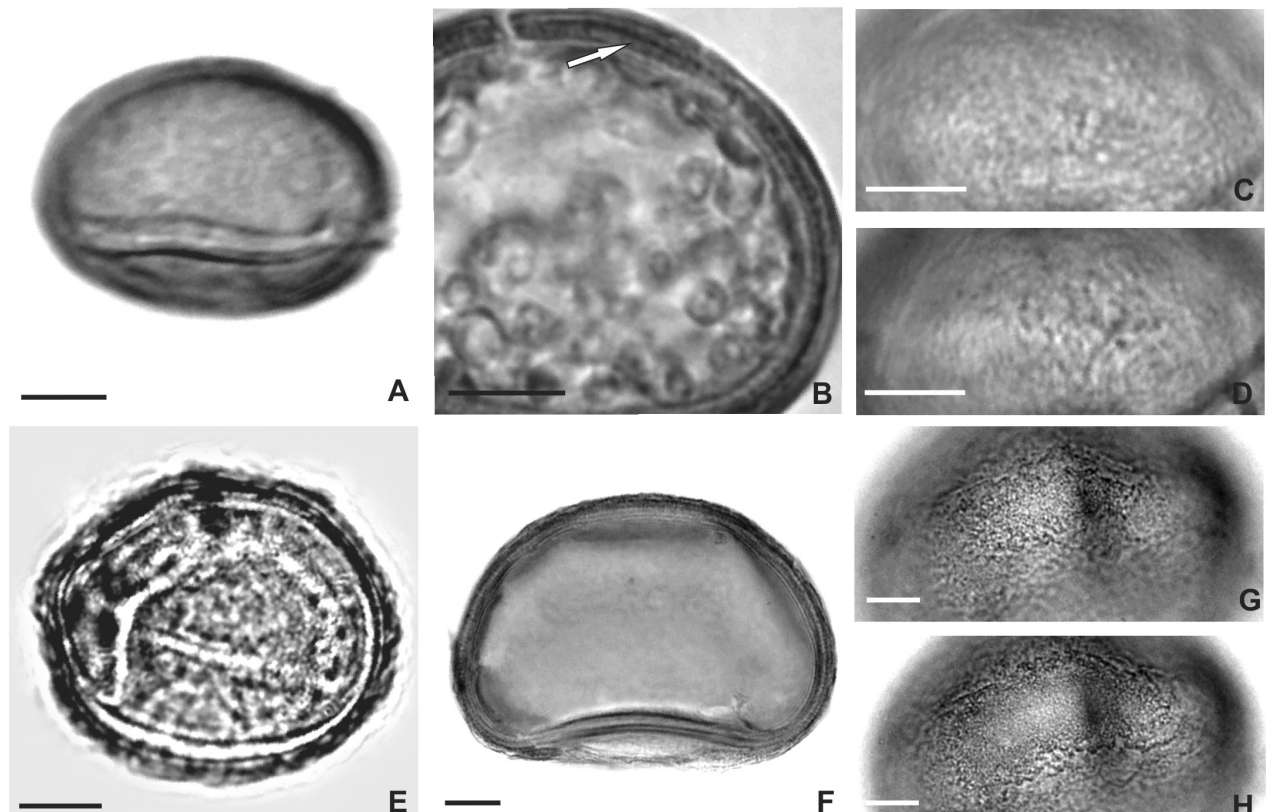

$\mathrm{E}$

\section{$\mathrm{F}$}
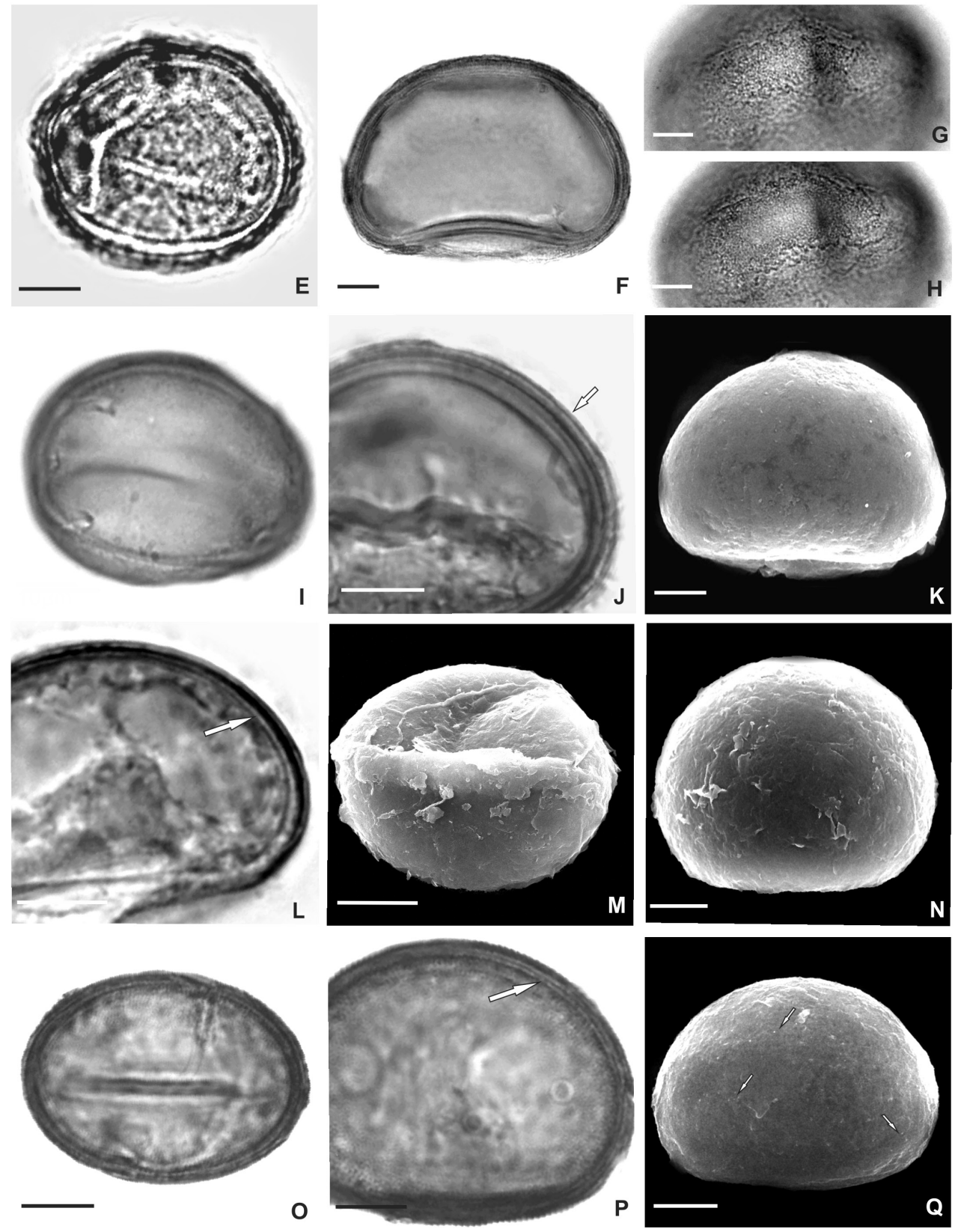

Figure 1. Photomicrographs and eletromicrographs of species of Austroblechnum: A. andinum. polar view: A. laesure (LM); equatorial view: B. optical section, exine and perine layers (arrow), (LM); C-D. L.O. analyses. A. divergens. polar view: E. laesure (LM); equatorial view: F. optical section; G-H. L.O. analysis. A. lehmannii. polar view: I. general aspect (ML); equatorial view: J. optical section, exine and perine layers (arrow), K. general aspect (SEM). A. penna-marina. equatorial view: L. optical section, exine and perine layers (arrow) (ML); polar view: M. laesure (SEM); equatorial view: N. general aspect (SEM). A. squamipes. polar view: O. laesure (LM); P. optical section, exine and perine layers (arrow), (LM); $\mathbf{Q}$. surface (the arrows indicate the granules-SEM). Scale bars: $A-Q=10 \mu \mathrm{m}$. 

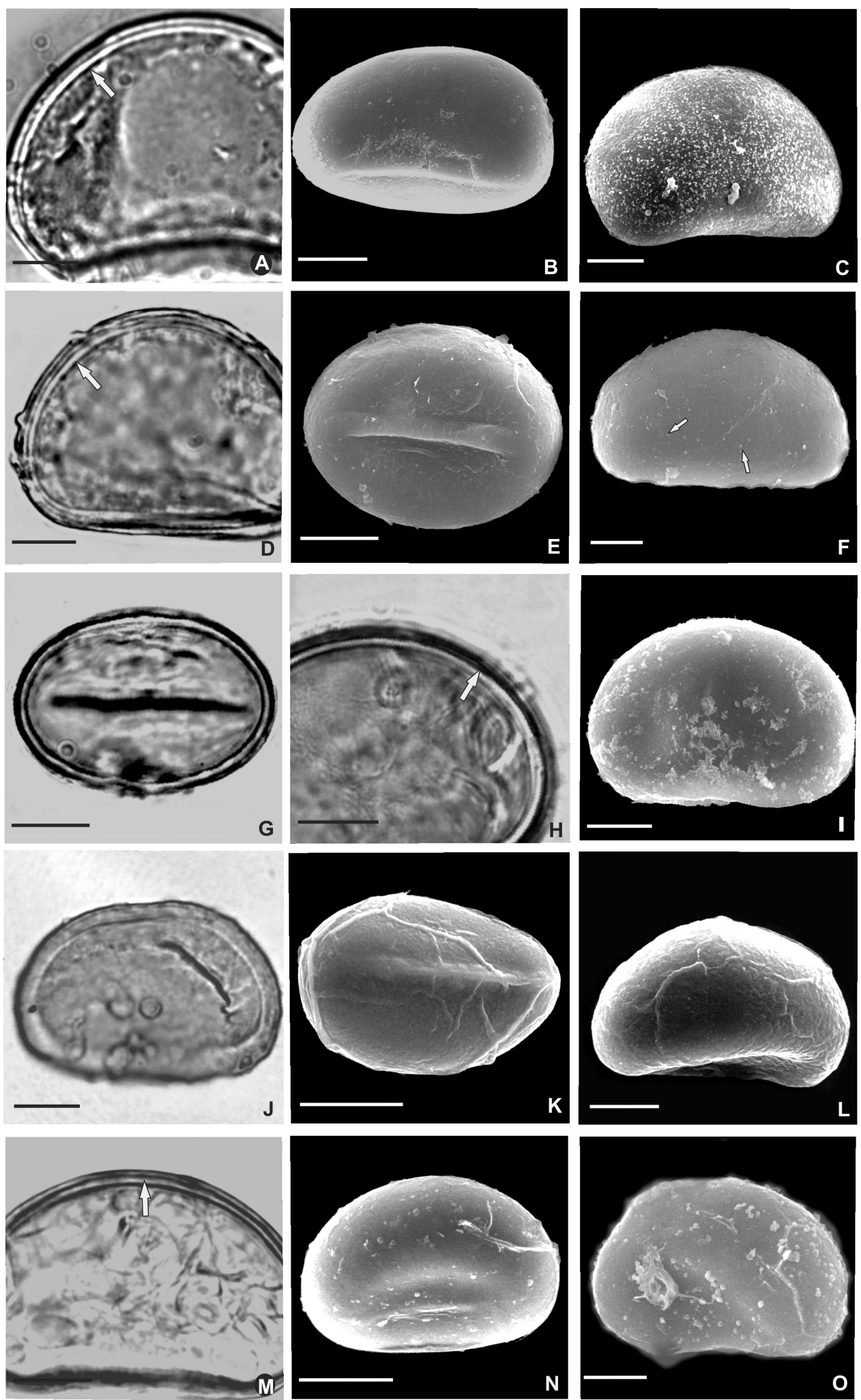

Figure 2. Photomicrographs and eletromicrographs of species of Blechnum. Blechnum asplenioides. equatorial view: A. optical section, exine and perine layers (arrow) (LM); B. general aspect (MEV); C. surface (MEV). B. auriculatum. equatorial view: D: optical section, exine and perine layers (arrow) (LM); polar view: E. laesure (SEM); F. equatorial view: surface (the arrows indicate the granules-SEM). B. austrobrasilianum. polar view: G. laesure (LM); equatorial view: H. optical section, exine and perine layers (arrow) (LM); I. surface (SEM). B. gracile. J. equatorial view: optical section (LM); polar view: K. laesure (SEM); equatorial view: L. surface (SEM). B. lanceola. equatorial view: M. optical section, exine and perine layers (arrow) (LM); polar view: N. laesure (SEM); equatorial view: $\mathbf{O}$. surface (SEM). Scale bars: A-O = $10 \mu \mathrm{m}$. 

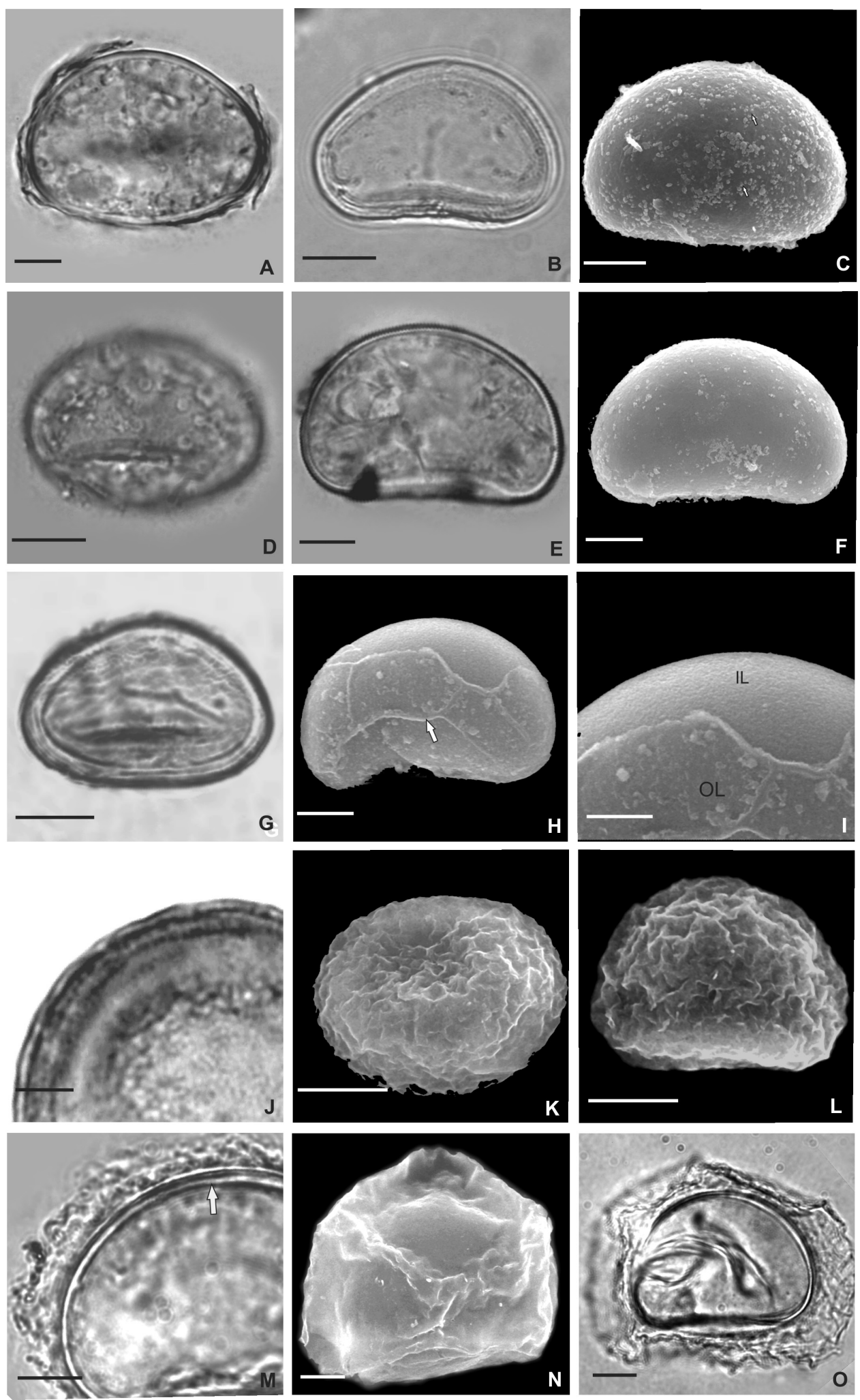

Figure 3. Photomicrographs and eletromicrographs of species of Blechnaceae. Blechnum occidentale. distal polar view: A. general aspect showing partially removed perine, (LM); equatorial view: B. optical section (LM); equatorial view: $\mathbf{C}$. general aspect and surface (SEM). B. polypodioides. polar view: D. general aspect and laesure; (LM); equatorial view: E. general aspect (LM) F. surface (SEM). B. $\mathrm{x}$ caudatum. polar view: G. general aspect and laesure (LM); equatorial view: H. "folds" on the surface (arrow) (SEM); I. surface (SEM). Cranfillia caudata.equatorial view: J. optical section, exine and perine layers (LM); polar view: K. general aspect (SEM); equatorial view: L. general aspect and surface (SEM). C. mucronata. equatorial view: M. optical section, exine and perine layers (LM); N. surface (SEM); O. perine detail (LM). Scale bars: A-L, O = $10 \mu \mathrm{m} ; \mathrm{J}, \mathrm{M}=5 \mu \mathrm{m}$. OL = outer layer; IL = innerlayer. 

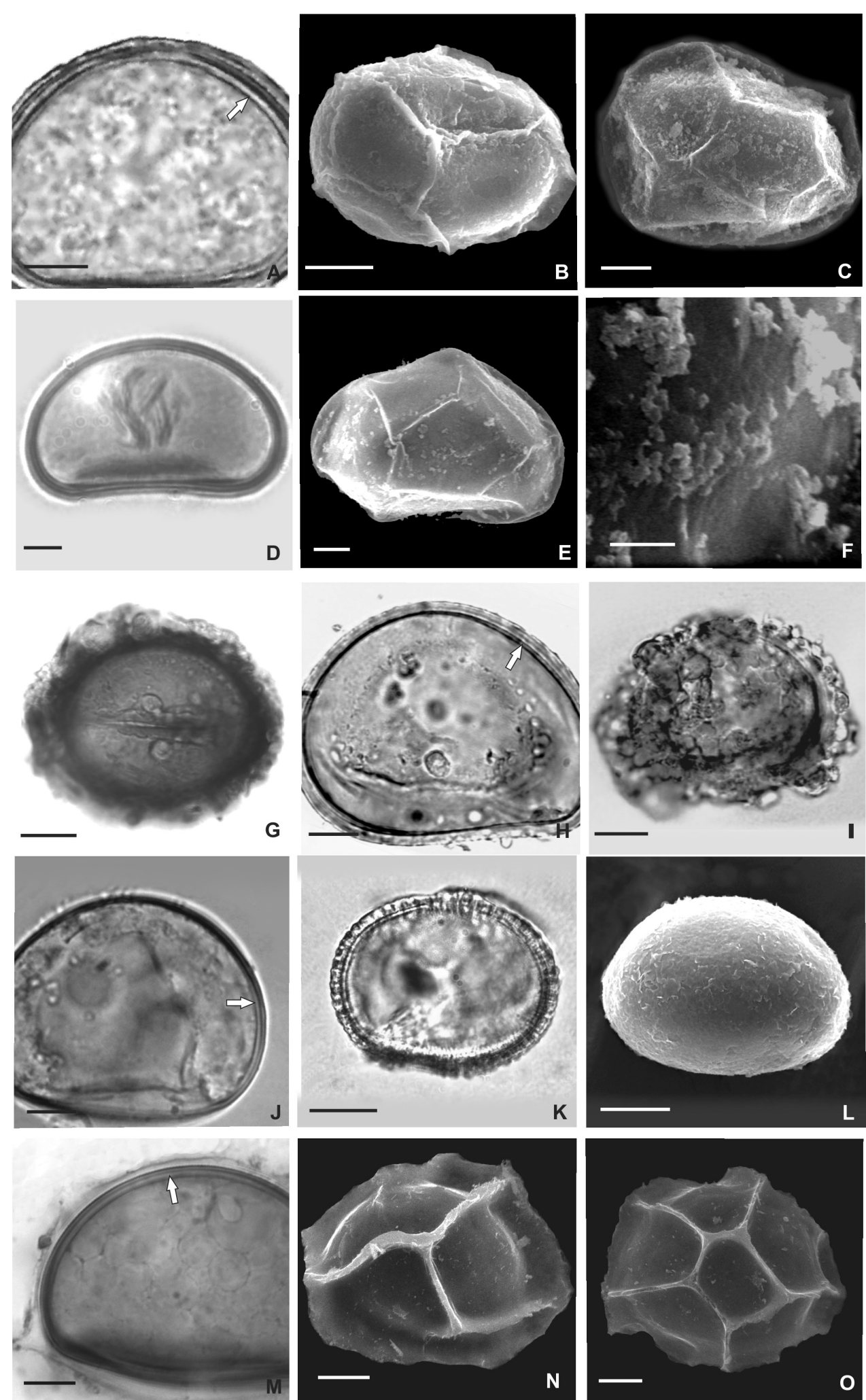

Figure 4. Photomicrographs and eletromicrographs of species of Blechnaceae. Lomaria spannagelii. equatorial view: A. optical section, exine and perine layers (LM); polar view: B. general aspect and surface (SEM); equatorial vew: C. surface (SEM). Lomaridium plumieri. equatorial view: D. optical section (LM); E. surface (SEM); F. detail surface (SEM). Lomariocycas schomburgkii. polar view: G. laesure (LM); equatorial view: H. optical section, exine and perine layers (LM); I. surface (LM). Neoblechnum brasiliense.equatorial view: J. optical section, exine and perine layers (LM); distal polar view: K. optical section (LM); L. surface (SEM); Parablechnum cordatum. equatorial view: $\mathbf{M}$. optical section, exine and perine layers (LM); equatorial vew: $\mathbf{N}$. surface (SEM);polar view: $\mathbf{O}$. general aspect and surface (SEM). Scale bars: A-O =10 $\mu \mathrm{m}$. 

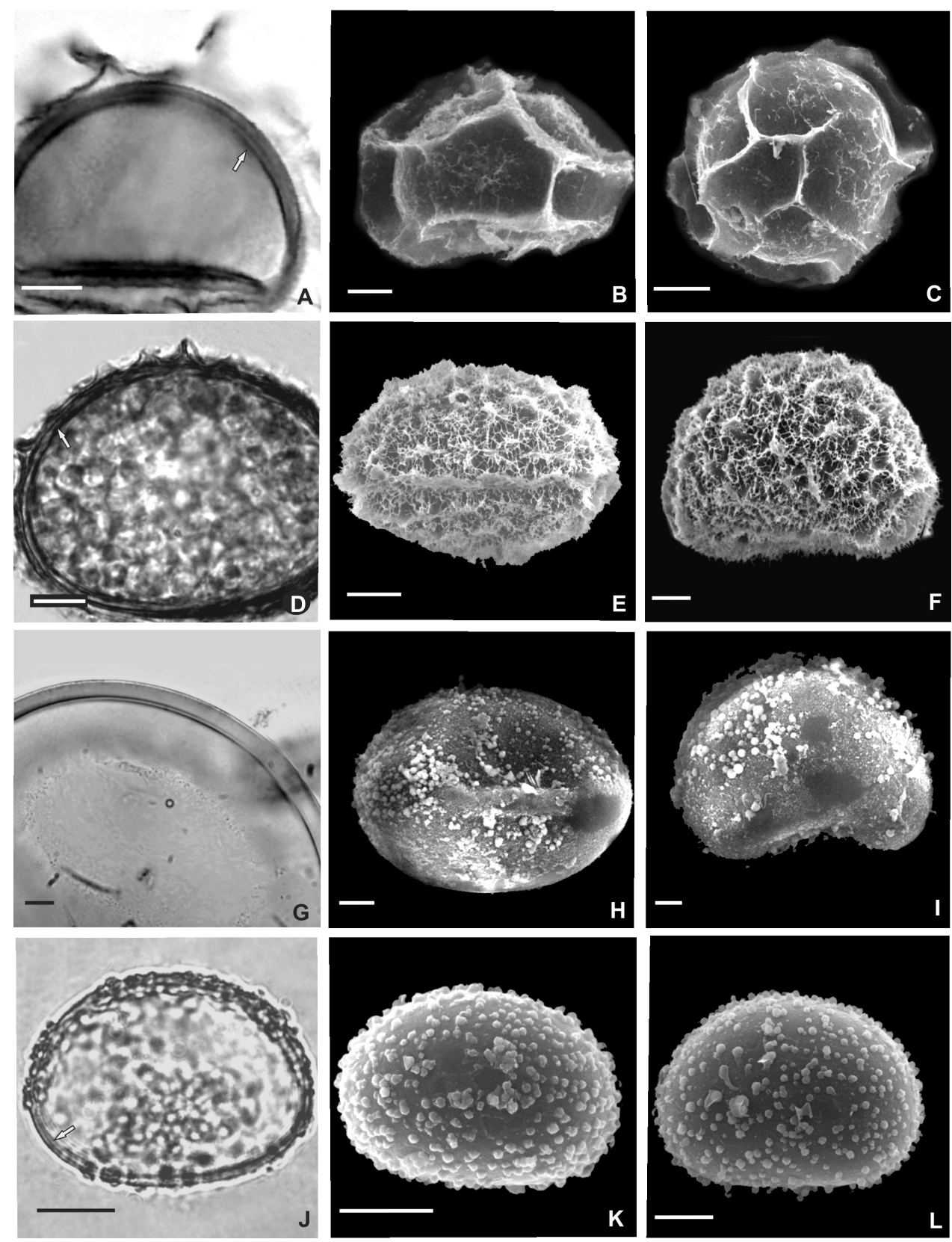

Figure 5. Photomicrographs and eletromicrographs of species of Blechnaceae. Parablechnum proliferum. equatorial view: A. optical section, exine and perine layers (LM); B. general aspect (SEM); distal polar view: C. general aspect and surface (SEM). P. usterianum. equatorial view: D. optical section, exine and perine layers (arrow) (LM); polar view: E. general aspect and surface (SEM); equatorial view: F. general aspect and surface (SEM). Salpichlaena volubilis. equatorial view: G. optical section, exine and perine layers (LM); polar view: H. laesure (SEM); equatorial view: I. general aspect and surface (SEM). Telmatoblechnum serrulatum. polar view: J. optical section, exine and perine layers; $\mathbf{K}$. surface (SEM); equatorial view: L. general aspect and surface (SEM). Scale bars: A-L =10 $\mu$ m.

prominence or projections), but is more evident in some species when analyzed under SEM such as Austroblechnum penna-marina (Fig. 1M) and Blechnum. auriculatum (Fig. 2E).

\section{Stratification of the exine and ornamentation of the perine}

The exine of taxa of Austroblechnum is psilate and composed of two layers (Fig. 1B, L): the sexine is as thick as the nexine in $A$. andinum; less thick than the nexine in $A$. divergens, A. lehmannii and A. penna-marina; and thicker than the nexine in A. squamipes (Tab. 3). The perine is thin, ca. $0.5 \mathrm{~mm}$ in $A$. andinum and $1.5 \mathrm{~mm}$ in A. lehmannii (Tab. 3), and composed of a single layer in most species; the exception being A. lehmannii, which has two layers with the inner layer thicker than the outer layer (Fig. 1J). The perine is granulate in $A$. andinum and $A$. divergens (Fig. $1 C, D, G, H$ ); and scabrate in A. lehmannii (Fig. 1K), A. penna-marina (Fig. 1L) 
Table 1. Measurements $(\mathrm{mm})$ in equatorial view of spores of species of Blechnaceae $(\mathrm{n}=25)$. Arithmetic mean $(\overline{\mathrm{X}})$ standard deviation $(\mathrm{S} \overline{\mathrm{X}})$ and confidence interval $(95 \% \mathrm{CI})$.

\begin{tabular}{|c|c|c|c|c|c|c|c|}
\hline \multirow{2}{*}{ Species } & \multicolumn{3}{|c|}{ Polar diameter (PD) } & \multicolumn{3}{|c|}{ Equatorial diameter (ED) } & \multirow{2}{*}{ Size } \\
\hline & Range & $\bar{X} \pm S \bar{x}$ & C.I. $95 \%$ & Range & $\bar{X} \pm s \bar{x}$ & C.I. $95 \%$ & \\
\hline Austroblechnum andinum & $25.0-32.5$ & $28.0 \pm 0.4$ & $27.0-29.0$ & $32.5-45.0$ & $38.4 \pm 0.5$ & $37.2-39.5$ & medium \\
\hline A. divergens & $32.5-50.0$ & $43.3 \pm 1.0$ & $41.5-45.4$ & $47.5-75.0$ & $61.0 \pm 1.3$ & $58.3-63.6$ & large \\
\hline A. lehmannii & $30.0-45.0$ & $36.0 \pm 0.6$ & $34.6-37.3$ & $42.5-50.0$ & $46.9 \pm 0.5$ & $45.8-47.9$ & medium \\
\hline A. penna-marina & $27.5-40.0$ & $32.1 \pm 0.5$ & $31.0-33.1$ & $37.5-52.5$ & $43.2 \pm 0.9$ & $41.2-45.1$ & medium \\
\hline A. squamipes & $35.0-40.0$ & $37.6 \pm 0.2$ & $37.1-38.0$ & $42.5-52.5$ & $48.4 \pm 0.4$ & $47.3-49.4$ & medium \\
\hline Blechnum asplenioides & $30.0-45.0$ & $35.1 \pm 0.6$ & $33.8-36.3$ & $42.5-72.5$ & $49.7 \pm 1.1$ & $47.3-50.0$ & medium \\
\hline B. auriculatum & $27.5-37.5$ & $32.4 \pm 0.4$ & 31.4-33.3 & $42.5-50.0$ & $45.7 \pm 0.5$ & $44.6-46.7$ & medium \\
\hline B. austrobrasilianum & $25.0-30.0$ & $27.8 \pm 0.3$ & 27.1-28.4 & $35.0-42.5$ & $39.4 \pm 0.5$ & $38.3-40.4$ & medium \\
\hline B. gracile & $20.0-35.0$ & $25.3 \pm 0.6$ & $23.8-26.7$ & $30.0-42.5$ & $36.5 \pm 0.6$ & $35.1-37.8$ & medium \\
\hline B. lanceola & $22.5-33.5$ & $26.9 \pm 0.5$ & $25.8-27.9$ & $32.5-47.5$ & $41.1 \pm 0.7$ & $39.6-42.5$ & medium \\
\hline Blechnum occidentale & $25.0-37.5$ & $31.8 \pm 0.5$ & $30.6-32.9$ & $37.5-50.0$ & $45.1 \pm 0.7$ & $43.5-46.6$ & medium \\
\hline B. polypodioides & $22.5-37.5$ & $30.3 \pm 0.8$ & 28.6-31.9 & $37.5-50.0$ & $45.0 \pm 0.8$ & $43.2-46.7$ & medium \\
\hline B. $x$ caudatum & $25.0-32.5$ & $28.8 \pm 0.5$ & $27.5-30.0$ & $37.5-50.0$ & $42.3 \pm 0.8$ & $40.5-44.0$ & medium \\
\hline Cranfillia caudata & $37.5-50.0$ & $44.1 \pm 0.7$ & $42.6-45.5$ & $50.0-72.5$ & $60.3 \pm 1.1$ & $57.8-62.7$ & large \\
\hline C. mucronata & $22.5-30.0$ & $25.7 \pm 0.3$ & $24.9-26.4$ & $30.0-40.0$ & $34.7 \pm 0.5$ & $33.4-35.9$ & medium \\
\hline Lomaria spannagelii & $27.5-42.5$ & $36.5 \pm 0.7$ & $34.6-37.7$ & $40.0-57.5$ & $48.9 \pm 0.8$ & $47.1-50.6$ & large \\
\hline Lomaridium plumieri & $37.5-55.0$ & $46.2 \pm 0.9$ & $44.2-48.1$ & $50.0-72.5$ & $60.5 \pm 1.2$ & $57.9-63.0$ & large \\
\hline Lomariocycas schomburkgii & $37.5-50.0$ & $43.8 \pm 0.6$ & $45.1-42.4$ & $55.5-67.5$ & $60.4 \pm 0.6$ & $59.0-61.7$ & large \\
\hline Neoblechnum brasiliense & $27.5-40.0$ & $32.8 \pm 0.7$ & $31.3-34.2$ & $40.0-55.0$ & $46.8 \pm 0.6$ & $45.3-48.2$ & medium \\
\hline Parablechnum cordatum & $55.0-70.0$ & $61.9 \pm 0,6$ & $60.4-63.3$ & $65.0-87.5$ & $76.9 \pm 1.3$ & $74.0-79.7$ & large \\
\hline P. proliferum & $37.5-50.0$ & $43.6 \pm 0.6$ & $42.2-44.9$ & $52.5-65.0$ & $58.5 \pm 0.5$ & $57.3-59.6$ & large \\
\hline P. usterianum & $30.0-52.5$ & $47.3 \pm 0.8$ & $45.4-49.1$ & $52.5-70.0$ & $64.9 \pm 1.0$ & $62.8-66.9$ & large \\
\hline Salpichlaena volubilis & $62.5-92.5$ & $74.2 \pm 1.5$ & 70.9-77.4 & $82.5-102.5$ & $93.3 \pm 1.3$ & $90.5-96.0$ & large \\
\hline Telmatoblechnum serrulatum & $27.5-47.5$ & $33.3 \pm 1.0$ & 31.1-35.4 & $37.5-50.0$ & $44.0 \pm 0.7$ & $42.3-45.6$ & medium \\
\hline
\end{tabular}

Table 2. Measurements $(\mu \mathrm{m})$ in polar view of spores of species of Blechnaceae $(n=10)$. Arithmetic mean $(\bar{X})$.

\begin{tabular}{|c|c|c|c|c|}
\hline Species & Range & $\begin{array}{l}\text { Larger diameter (LD) } \\
\overline{\bar{x}}\end{array}$ & Range & $\begin{array}{c}\text { Smallest diameter (SD) } \\
\overline{\bar{x}}\end{array}$ \\
\hline Austroblechnum andinum & $37.5-40.0$ & 38.0 & $25.0-27.5$ & 26.5 \\
\hline A. divergens & $50.0-72.5$ & 64.2 & $35.0-45.0$ & 40.0 \\
\hline A. lehmannii & $45.0-50.0$ & 47.5 & $35.0-37.5$ & 36.5 \\
\hline A. penna-marina & $37.5-50.0$ & 45.0 & $27.5-37.5$ & 34.5 \\
\hline A. squamipes & $45.0-52.5$ & 48.0 & $35.0-37.5$ & 37.0 \\
\hline Blechnum asplenioides & $45.0-52.5$ & 49.0 & $25.0-47.5$ & 34.0 \\
\hline B. auriculatum & $40.0-47.5$ & 44.5 & $27.5-37.5$ & 33.7 \\
\hline B. austrobrasilianum & $25.0-30.0$ & 26.2 & $35.0-37.5$ & 37.0 \\
\hline B. gracile & $30.0-40.0$ & 35.0 & $22.5-30.0$ & 24.0 \\
\hline B. lanceola & $37.5-47.5$ & 42.2 & $25.0-32.5$ & 29.0 \\
\hline B. occidentale & $35.0-50.0$ & 42.5 & $27.5-42.5$ & 32.5 \\
\hline B. polypodioides & $37.5-45.0$ & 40.2 & $25.0-27.5$ & 25.7 \\
\hline B. $x$ caudatum & $37.5-50.0$ & 41.7 & $25.0-32.5$ & 29.0 \\
\hline Cranfillia caudata & $45.0-67.5$ & 61.0 & $37.5-50.0$ & 46.0 \\
\hline C. mucronata & $30.0-37.5$ & 32.7 & $20.0-27.5$ & 24.2 \\
\hline Lomaria spannagelii & $45.0-62.5$ & 52.2 & $35.0-45.0$ & 38.0 \\
\hline Lomaridium plumieri & $52.5-62.5$ & 58.7 & $32.5-40.0$ & 37.5 \\
\hline Lomariocycas schomburkgii & $55.0-65.0$ & 60.2 & $40.0-50.0$ & 44.2 \\
\hline Neoblechnum brasiliense & $42.5-50.0$ & 44.7 & $25.0-32.5$ & 27.7 \\
\hline Parablechnum cordatum & $67.5-90.0$ & 79.2 & $50.0-65.0$ & 59.5 \\
\hline P. proliferum & $55.0-62.5$ & 59.2 & $37.5-50.0$ & 43.5 \\
\hline P. usterianum & $57.5-72.5$ & 65.7 & $37.5-60.0$ & 47.5 \\
\hline Salpichlaena volubilis & $52.5-72.5$ & 65.0 & $37.5-57.5$ & 49.0 \\
\hline Telmatoblechnum serrulatum & $37.5-50.0$ & 43.2 & $25.0-35.0$ & 28.0 \\
\hline
\end{tabular}


Table 3. Measurements ( $\mu \mathrm{m})$ in equatorial view of the exine, perine layers and leasure of spores, of species of Blechnaceae species $(\mathrm{n}=10)$. Arithmetic mean $(\overline{\mathrm{X}}) ;{ }^{*}$ insufficient amount for analysis / sensitive to acetolysis.

\begin{tabular}{|c|c|c|c|c|c|}
\hline \multirow{2}{*}{ Species } & \multicolumn{3}{|c|}{ Exine } & \multirow{2}{*}{$\begin{array}{c}\text { Perine } \\
\bar{x}\end{array}$} & \multirow{2}{*}{$\begin{array}{c}\text { Laesure } \\
\overline{\bar{x}}\end{array}$} \\
\hline & Nexine $\bar{x}$ & Sexine $\bar{X}$ & Total & & \\
\hline Austroblechnum andinum & 1.0 & 1.0 & 2.0 & 0.5 & 11.2 \\
\hline A. divergens & 1.1 & 1.0 & 2.1 & 1.0 & 15.4 \\
\hline A. lehmannii & 1.1 & 0.9 & 2.0 & 1.5 & 14.6 \\
\hline A. penna-marina & 1.2 & 0.9 & 2.1 & 0.9 & 11.4 \\
\hline A. squamipes & 0.5 & 0.7 & 1.2 & 1.0 & 12.8 \\
\hline Blechnum asplenioides & 1.0 & 1.0 & 2.0 & 0.8 & 12.4 \\
\hline B. auriculatum & 1.0 & 1.0 & 2.0 & 1.0 & 10.7 \\
\hline B. austrobrasilianum & 0.9 & 1.0 & 1.9 & * & 10.5 \\
\hline B. gracile & 0.7 & 1.6 & 2.3 & * & 9.8 \\
\hline B. lanceola & 0.8 & 0.7 & 1.3 & * & 12.7 \\
\hline B. occidentale & 0.8 & 0.9 & 1.7 & 0.8 & 11.7 \\
\hline B. polypodioides & 0.9 & 1.1 & 2.0 & * & 11.4 \\
\hline B. $x$ caudatum & 0.9 & 0.8 & 1.8 & 0.6 & 9.8 \\
\hline Cranfillia caudata & 0.9 & 1.0 & 1.8 & 8.3 & 11.3 \\
\hline C. mucronata & 0.9 & 1.0 & 1.9 & $*$ & 9.1 \\
\hline Lomaria spannagelii & 0.7 & 0.7 & 1.5 & * & 15.1 \\
\hline Lomaridium plumieri & 1.0 & 1.6 & 2.6 & 7.0 & 14.3 \\
\hline Lomariocycas schomburkgii & 1.0 & 1.2 & 2.2 & * & 15.0 \\
\hline Neoblechnum brasiliense & 0.6 & 0.9 & 1.6 & * & 11.4 \\
\hline Parablechnum cordatum & 1.0 & 1.0 & 2.0 & 9.1 & 20.9 \\
\hline P. proliferum & 0.9 & 1.9 & 2.8 & 11.0 & 18.0 \\
\hline P. usterianum & 1.2 & 1.0 & 2.1 & 5.6 & 19.6 \\
\hline Salpichlaena volubis & 1.0 & 2.0 & 3.0 & 0.5 & 14.4 \\
\hline Telmatoblechnum serrulatum & 0.7 & 0.9 & 1.7 & * & 12.8 \\
\hline
\end{tabular}

and A. squamipes (Fig. 1P, Q). Desquamation of the perine has a foliose appearance (Fig. 1M), and is fragile to acetolysis in $A$. andinum and $A$. penna-marina.

The exine of taxa of Blechnum is psilate and composed of two layers (Fig. 2A, D, H): the sexine is as thick as the nexine in $B$. asplenioides, $B$. auriculatum, B. austrobrasilianum and $B$. occidentale; less thick than the nexine in B. lanceola; and thicker than the nexine in B. gracile and B. polypodioides (Tab. 3). The perine is thin and composed of a single layer in most species, with thickness varying from 0.6 to 1.0 $\mu \mathrm{m}$ (Tab. 3); the presence of two layers was observed in $B$. $\times$ caudatum (Fig. 3I). The perine was not measured for $B$. austrobrasilianum, B. gracile, B. lanceola and B. polypodioides because it was too fragile for $40 \%$ lactic acetolysis. Perine showed five ornamentation pattern: granulate in $B$. asplenoides (Fig. 2C) and B. occidentale (Fig. 3C); psilate with scarce granules in B. auriculatum (Fig. 2F); psilate in B. austrobrasilianum (Fig. 2I) and B. lanceola (Fig. 2N, O) and B. polypodioides (Fig. 3F); and scabrate with "folds" which are distributed over the entire surface, bounding the areas where the granules are located, in $B . \times$ caudatum (Fig. 3H, I); rugulate with "folds" on the surface in $B$. gracile (Fig. 2K, L).

The exine of taxa of Cranfillia is psilate and composed of two layers (Fig. 3M), which are difficult to visualize in C. caudata (Fig. 3J), while the sexine is thicker than the nexine in both species. The perine is thick in C. mucronata
$(8.3 \mu \mathrm{m})$, it was not measured in C. caudata because of its fragility (Tab. 3) and has two layers, an internal "spongiose" layer that supports the external layer, which is cristate with elevations delimiting depressions (Fig. 3N). The surface of the spore of $C$. caudata possess thin and smooth cristae that form reticula of fine walls throughout (Fig. 3J, K).

The exine of Lomaria spannagelii is psilate and composed of two layers, with the sexine being as thick as the nexine (Fig.4A, Tab.3). The perine forms cristae at the poles with rugulae conspicuous in polar view (Fig.4B), less evident in equatorial view (Fig.4C) and granules, which are fragile and were removed during $40 \%$ lactic acetolysis (Tab. 3 ).

The exine of Lomaridium plumieri is psilate and composed of two layers (Fig. 4D), with the perine being thick. The ornamentation forms cristae at the poles with inconspicuous rugulae on the surface and microgranules (Fig. 4E, F).

The exine of Lomariocycas schomburgkii is psilate and composed of two layers (Fig. $4 \mathrm{H}$ ), with the sexine being thicker than the nexine. The perine is densely gemmate (Fig. 4I), very fragile, and was removed (Fig. 4H) during $40 \%$ lactic acetolysis (Tab. 3 ).

The exine of Neoblechnum brasiliense is psilate and composed of two layers (Fig. 4J), with the the sexine is thicker than the nexine (Tab. 3). The perine is scabrate (Fig. 4K, L), very fragile, and was removed during $40 \%$ lactic acetolysis (Tab. 3).Desquamation of the foliose-looking perine was apparent. 
The exine of Parablechnum is psilate and composed of two layers (Fig. 4M, 5A): the sexine being thicker than the nexine in $P$. proliferum; less thick than the nexine in $P$. usterianum; and of the same thickness in P. cordatum (Tab. 3). The perine varied in thickness from 5.6 to $11.0 \mu \mathrm{m}$ (Tab. 3), and had smooth cristae with broad folds forming visibly larger muri with discrete filaments dispersed across the surface in P. cordatum (Fig. 4N, O) and P. proliferum (Fig. $5 \mathrm{~B}, \mathrm{C}$ ), while the cristae of $P$. usterianum were difficult to visualize due to the ornamentation pattern of reticula formed by a dense layer of more conspicuous filaments (Fig. 5E, F).

The exine of Salpichlaena volubilis is psilate and composed of two layers (Fig. 5G), with the sexine being thicker than the nexine (Tab. 3). The perine is thin, ca. $0.5 \mathrm{~mm}$ (Tab. 3), with granulate-gemmate ornamentation with granules and gemmae of varying dimensions randomly dispersed across the surface and forming larger groupings in some regions (Fig. 5H, I).

The exine of Telmatoblechnum serrulatum is psilate and composed of two layers (Fig. 5J), with the sexine being thicker than the nexine (Tab. 3). The perine is fragile and with granules and gemmae distributed across the surface (Fig 5K, L).

\section{Hierarchical Cluster Analysis (HCA)}

Cluster analysis produced a dendogram with a binding value of $5.88 \%$. When $50 \%$ of the information was analyzed two groups were formed: Group 1 contained Austroblechnum andinum, Blechnum lanceola, B. x caudatum, B. polypodioides, Telmatoblechnum serrulatum ${ }_{2}$ A. penna-marina, $B$. auriculatum, B. occidentale, Neoblechnum brasiliense, $A$. lehmannii, A. squamipes, B. asplenioides, Lomaria spannagelii, B. austrobrasilianum, B. gracile and Cranfillia caudata; Group 2 contained $A$. divergens, Lomariocycas schomburkgii, Lomaridium plumieri, C. mucronata, Parablechnum proliferum, P. usterianum P. cordatum and Salpichlaena volubilis (Fig. 6).

Although Group 1 had a greater number of species with similar data, some subgroups were formed based on quantitatives data of some species. Such groupings were also evidenced by the PCA, which individualized taxa, revealing some attributes and the differentiation of some species. Analysis of the subgroups of Group 1 revealed that Austroblechnum andinum was separated from Blechnum lanceola and B. $x$ caudatum due to it having the lowest values for PD, ED, LD and SD; Telmatoblechnum serrulatum was differentiated by having greater values for PD, LD, SD than B. polypodioides; Neoblechnum brasiliense was differentiated by having the smallest value for SD; Lomaria spannagelii stood out with the highest value for LD; B. austrobrasilianum was separated from the other taxa of its subgroup by having the highest values for PD, ED and SD.

Analysis of Group 2 revealed Austroblechnum divergens and Lomariocycas schomburkgii to be more similar to each

\begin{tabular}{|c|c|c|c|c|}
\hline \multicolumn{5}{|c|}{ PCA } \\
\hline 3.6E++00 & $3.3 \mathrm{E}+03$ & Distance (Objective Function) & $1 E+04$ & $1.3+04$ \\
\hline 100 & 75 & Information Remaining (\%) & 25 & \\
\hline
\end{tabular}

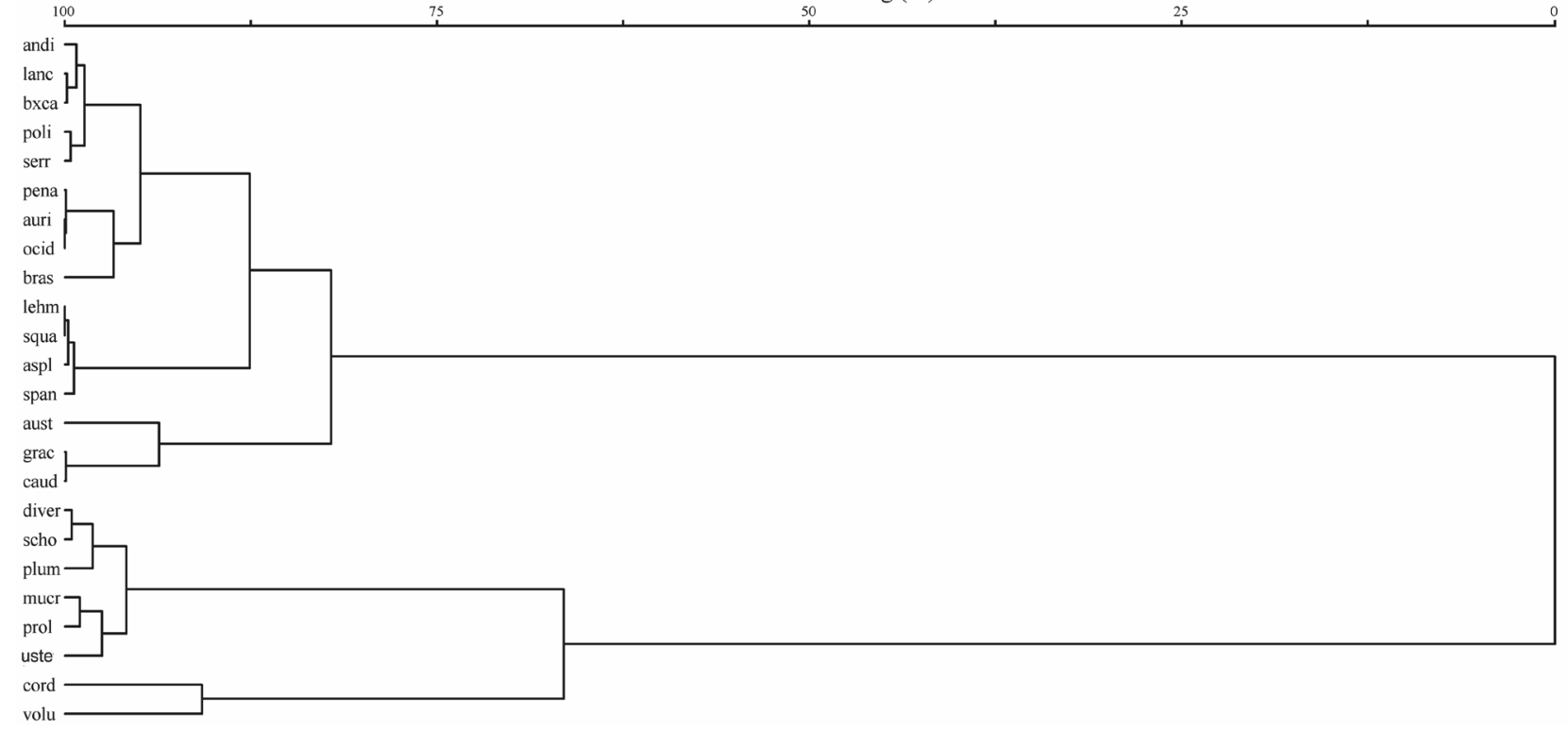

Figure 6. Cluster analysis of measured variables of the spores of species of the family Blechnaceae. Abbreviations: andi = Austroblechnum andinum, dive $=A$. divergens, lehm $=A$. lehmannii, pena $=A$. penna-marina, squa $=A$. squamipes, aspl $=$ Blechnum asplenioides, auri $=$ B. auriculatum, aust $=B$. austrobrasilianum, graci $=B$. gracile, lanc $=B$. lanceola, ocid $=B$. occidentale, poli $=B$. polypodioides, bxca $=B . x$ caudatum, caud = Cranfillia caudata, mucr $=$ C. mucronata, span $=$ Lomaria spannagelii, plum = Lomaridium plumieri, scho $=$ Lomariocycas schomburkgii, bras $=$ Neoblechnum brasiliense, cord $=$ Parablechnum cordatum, prol $=$ P. proliferum, uste $=$ P. usterianum, volu $=$ Salpichlaena volubis, serr = Telmatoblechnum serrulatum. 
other than to Lomaridium plumieri, which was distinguished by its higher value for ED; Cranfillia mucronata and Parablechnum proliferum had similar values for PD and ED, while $P$. usterianum was highlighted in this subgroup by having the highest value for ED; P. cordatum and Salpichlaena volubilis had the highest values for PD and ED of all the species studied.

The first two axes of the PCA explained $95.04 \%$ of the total variance (Fig. 7). Both of these axes were significant and explained $89.88 \%$ and $5.16 \%$ of the variance, respectively. The most significant variables of the first axis were ED, $\mathrm{LD}, \mathrm{PD}$ and $\mathrm{SD}$, while those of the second axis were ED, PD, LD and SD.

The negative side of the first axis had few sparse species, evidencing the distinctness of the group. The opposite occurred on the positive side of the same axis, where the species Parablechnum cordatum and Salpichlaena volubilis were isolated from the others on the PCA graph because they had the highest LD $(79.2 \mu \mathrm{m})$ and higher ED (93.3 $\mu \mathrm{m})$, respectively; and polarized from each other because Salpichlaena volubilis was at the positive pole of axis 2 while Parablechnum cordatum was at the negative pole. Lomaridium plumieri was located in the same quadrant of the PCA graph as Salpichlaena volubilis because it had the lowest values for PD (42.3 mm), LD (58.7 mm) and SD $(37.5 \mathrm{~mm})$.

\section{Discussion}

Morphometric analysis revealed variation in spore size among genera and among species of the same genus, such as in Austroblechnum where A. divergens had large pollen while the pollen of it congeners was medium-sized.
Likewise, large and medium-sized spores were recorded for Cranfillia mucronata and C. caudata, respectively. Meanwhile, all species of Blechnum had medium-sized spores.

Passarelli et al. (2010) described Austroblechnum divergens as having medium-sized spores and Blechnum auriculatum and B. occidentale as having large spores, which differs from the findings of the present study. This difference in size can be due to several factors, such as the methodology used for spore analysis and environmental factors, as cited by Salgado-Labouriau (1973) and Barth \& Melhem (1988). Erdtman (1969) also reported that polyploid species may vary in size and volume. Polyploidy is recognized as promoting the expression of several genes, and consequently morphological variability, among pteridophytes (Sigel 2016).

Perine ornamentation varied widely among the studied genera and species. The perine was found to be psilate, rugulate, cristate, granulate and gemmate, but in the majority of species it was scabrate and associated with other ornamentations. This attribute was the most relevant to characterizing genera. The ornamentation of Austroblechnum was granulate or psilate, while for Blechnum the perine ranged among granulate, psilate with or without granules, scabrate and rugulate. A cristate perine was recorded for Cranfillia and Parablechnum. The ornamentation of the perine of the hybrid B. $\times$ caudatum was scabrate with "folds" and granules on the surface; a morphology also found in $B$. occidentale, one of its parent species.

Moran et al. (2018) reported that the perine of Austroblechnum ad Blechnum is smooth and without verrucae or sulcus or any microstructures. Passarelli et al (2010) cited microgranules for two species of Austroblechnum, but with a psilate perine. Coelho \& Esteves (2008) also mentioned the



Figure 7. Principal component analysis of measured variables of the spores of species of the family Blechnaceae. Abbreviations: Austroblechnum $=\bullet$, Blechnum $=\otimes$, Cranfillia $=\mathbf{\wedge}$, Lomaria $=\boldsymbol{\Delta}$, Lomaridium $=\mathbf{0}$, Lomariocycas $=\diamond$, Neoblechnum $=\bullet$, Parablechnum $=\mathbf{\wedge}$, Salpichlaena $=\boldsymbol{\varphi}$, Telmatoblechnum $=\nabla$. andi $=$ Austroblechnum andinum, dive $=A$. divergens, lehm $=A$. lehmannii, pena $=A$. penna-marina, squa $=$ A. squamipes, aspl = Blechnum asplenioides, auri $=B$. auriculatum, aust $=B$. austrobrasilianum, graci $=B$. gracile, lanc $=B$. lanceola, ocid = B. occidentale, poli $=$ B. polypodioides, bxca = B. $x$ caudatum, caud = Cranfillia caudata, mucr $=$ C. mucronata, span = Lomaria spannagelii, plum = Lomaridium plumieri, scho = Lomariocycas schomburkgii, bras = Neoblechnum brasiliense, cord $=$ Parablechnum cordatum, prol = P. proliferum, uste $=$ P. usterianum, volu $=$ Salpichlaena volubilis, serr $=$ Telmatoblechnum serrulatum. 
presence of granulations for B. polypodioides. Eight species of the present study possessed granules (Austroblechnum andinum, $A$. divergens, Blechnum asplenioides, B. auriculatum, B. austrobrasilianum, B. lanceola, B. occidentale and B. polypodioides) while one species possessed rugulae (B. gracile).

Principal components analysis revealed the grouping of these species at the negative side of axis 1 , demonstrating their similarity with regard to the quantitative data, with the exception of Austroblechnum divergens, which was located on the negative side of axis 2 and grouped with other genera because it had the highest value for LD (larger diameter).

Desquamation of the perine was observed in Austroblechnum penna-marina, which gave it a foliose appearance, as also observed by Tryon \& Lugardon (1990) and Coelho \& Esteves (2008).

Neoblechnum brasiliense and Salpichlaena volubilis possesses scabrate perine, however granules and gemmae of varying sizes forming clusters in some regions was recorded only for S. volubilis. This characteristic was also observed by Tryon \& Tryon (1982), Tryon \& Lugardon (1990) and Moran et al (2018), who used the term "spherule". The PCA highlights this species on the positive side of axis 2 due it having the highest diameter equatorial (DE) value of all the species analyzed, while cluster analysis grouped it with Parablechnum cordatum.

Morbelli et al. (2009) and Passarelli et al. (2010) described Cranfillia caudata (= Blechnum sprucei) as having a rugose perine with folds, which differs from the ornamentation found in the present study (thin and smooth with cristae forming reticula). Moran et al. (2018) did not use the term "cristate" when they describe the ornamentation of the spores of genus Cranfillia as extensively folded, but they did emphasize a second spongy layer, as also observed in the present study for $C$. mucronata. The species were distinctly separated in the multivariate analysis by the values of equatorial diameter (DE) obtained for C. caudata.

Passarelli et al. (2010) described the spores of Lomaria spannagelii as having wrinkles and being roughly folded, while Moran et al. (2018) described them as widely folded, both of which differ from what was found by the present study for this species (cristate). Furthermore, although a different genus, Moran et al. (2018) describes the same ornamentation for Lomaridium plumieri. The positions of these species along the multivariate axes were distinct, resulting from the higher equatorial diameter (DE) for L. plumieri, although they had the same values for larger diameter (LD).

Coelho \& Esteves (2008) analyzed Parablechnum proliferum, and classified the perine as micro-rugulate with projections, while Moran et al. (2018) considered it as folded with filaments. The species of Parablechnum of the present study had a perine with crests and the presence of filaments with different degrees of intensity for each species, which differs from the ornamentation described in the studies cited above, agreeing only in the presence of filaments.
In his work on the Itatiaia Plateau, Sylvestre (1995) described Lomariocycas schomburkgii as having sharp ripples similar to warts, and even broad cristae. Tryon \& Tryon (1982) and Passarelli et al. (2010) described the ornamentation of this species as densely rugulate. The present study differs from the aforementioned authors since the perine was recorded as densely gemmate. The divergence in the description may be related to the methodology used, the perine of the mentioned species showed fragility to the process of acetolysis and SEM, therefore was used for the description the Wodehouse method that maintains the integral perine. Perhaps the methodology used by these authors has broken the surface ornamentation of the perine causing the divergence observed here.

The present study found the perine of Telmatoblechnum serrulatum to have granules and gemmae distributed across the surface, which is in agreement with Tryon \& Tryon (1982), Passarelli et al. (2010), Dittrich et al. (2007) and Moran et al. (2018).

\section{Conclusion}

The morphological variation of the perine among the species evaluated in the present study revealed that: Austroblechnum and Blechnum are eurypalynous; the ornamentation of the perine of Cranfillia caudata, Parablechnum proliferum and Lomariocycas schomburkgii differ from that reported by previous studies; and Lomaria and Lomaridium possess the same ornamentation. The present study revealed different characteristics of the ornamentation of the perine that allowed the differentiation of species of the analyzed genera, demonstrating that palynology is an important tool for the differentiation of taxa.

Although the spore morphology of some species of Blechnaceae is very similar, the multivariate analysis highlighted the importance of quantitative traits for differentiating species.

\section{Acknowledgements}

We thank the technique and Professor Ana Furtado of the Polymer Laboratory of the Chemistry Institute of the State University of Rio de Janeiro (UERJ), for providing technical assistance with SEM, and the curators of the herbariums for the samples they provided. The authors, V. Gonçalves-Esteves and Mendonça C.B.F., thank CNPq (Conselho Nacional de Desenvolvimento Científico e Tecnológico) for the research grant.

\section{References}

Almeida GS, Mezzonato-Pires AC, Mendonça CBF, Gonçalves-Esteves V. 2018. Pollen morphology of selected species of Piriqueta Aubl. (Passifloraceae sensu lato). Palynology 43:43-52.

Barth OM, Melhem TS. 1988. Glossário ilustrado de palinologia. Campinas, Unicamp. 
Caccavari MA, Naab AO, Tamame MA. 2008. Palynological and physicochemical characteristics of three unifloral honey types from central Argentina. Spanish Journal of Agricultural Research 6: 566-576.

Coelho CB, Esteves LM. 2008. Morfologia de esporos de pteridófitas do Parque Estadual das Fontes do Ipiranga (São Paulo, Brasil): Blechnaceae. Hoehnea 35:387-393.

Dittrich VAO, Heringer G, Salino A. 2007. Blechnaceae. In: Cavalcanti TB, Ramos AE. (eds.) Flora do Distrito Federal. Brasília, Embrapa Recursos Genéticos e Biotecnologia, p. 91-108.

Erdtman G. 1952. Pollen morphology and plant taxonomy - angiosperm. Stockholm, Almqvisit \&Wiksell.

Erdtman G. 1969. Handbook of palynology. Morphology, taxonomy, ecology. New York, Hafner Publishing.

Erdtman G, Sorsa P. 1971. Pollen and spore morphology and plant taxonomy: Pteridophyta. Stockholm, Almqvist \& Wiksell.

Flora do Brasil 2020 [em construção]. 2018. Blechnaceae. Rio de Janeiro, Jardim Botânico do Rio de Janeiro. http://floradobrasil.jbrj.gov.br/ reflora/floradobrasil/FB90784. 30 Sep. 2018.

Gasper AL, Almeida TE, Dittrich VAO, Smith AR, Salino A. 2017. Molecular phylogeny of the fern family Blechnaceae (Polypodiales) with a revised genus-level treatment. Cladistics 33: 429-446.

Gasper AL, Dittrich VAO, Smith AR, Salino A. 2016. A classification for Blechnaceae (Polypodiales: Polypodiopsida): new genera, resurrected names, and combinations. Phytotaxa 275: 191-227.

Giacosa JPR, Morbelli MA, Giúdice GE. 2009. Spore morphology and wall ultrastructure of Blechnum L. species from North West Argentina. Review of Paleobotany and Palynology 156: 185-197.

Lloyd RM. 1976. Spore Morphology of the Hawaiian Genus Sadleria (Blechnaceae). American Fern Journal 66: 1-7.

McCune B, Mefford MJ. 2011. PC-ORD. Multivariate analysis of ecological data. Version 6. Gleneden Beach, MjM Software.

Melhem TS, Cruz-Barros MAV, Corrêa MAS, Makino-Watanabe H, SilvestreCapelato MS, Esteves VLG. 2003. Variabilidade polínica em plantas de Campos do Jordão (São Paulo, Brasil). Boletim do Instituto de Botânica 16: 1-104.

Moran RC, Hanks JG, Labiak PH. 2018. Evolution of spore morphology in the Blechnaceae. International Journal of Plant Sciences 179: 712729.

Morbelli MA. 1974. Análisis palinológico en híbridos interespecíficos del gênero Blechnum L. subgénero Blechnum (Blechnacaee-Pteridophyta). Boletin Sociedade Argentina de Botanica 15: 447-465.

Morbelli MA. 1976. Estudio palinológico de lasespeciesaustrosudamericanas Del género Blechnum L. subgénero Blechnum (BlechnaceaePteridophyta). Boletin Sociedade Argentina de Botanica 17: 155-175.

Morbelli MA, Ramos Giacosa JP, Giudice GE. 2009. Spore morphology and wall ultrastructure of Blechnum L. species form North West Argentina. Review of Paleobotany and Palynology 156: 185-197.
Passarelli LM. 2007. Estudios esporales en species Del grupo Blechnum penna-marina (Blechnaceae-Pteridophyta). Acta Botanica Malacitana 32: 49-66.

Passarelli LM, Galán JMG, Prada C, Rolleri CH. 2010. Spore morphology and ornamentation in the genus Blechnum (Blechnaceae). Grana 49: 243-262.

PPG I - The Pteridophyte Phylogeny Group. 2016. A community-derived classification for extant lycophytes and ferns. Journal of Systematics and Evolution 54: 563-603.

Punt W, Hoen PP, Blackmore S, Nilsson S, Thomas A. 2007. Glossary of pollen and spore terminology. Review of Paleobotany and Palynology 143: 1-81.

Raynal J, Raynal A. 1971.Une technique de preparation des grains de pollen fragiles. Andansonia 11: 77-79.

Rothfels CJ, Sundue MA, Kuo LY, et al. 2012. A revised family-level classification for eupolypod II ferns (Polypodiidae: Polypodiales). Taxon 61: 515-533.

Salgado-Labouriau ML. 1973. Contribuição à palinologia dos cerrados. Rio de Janeiro, Academia Brasileira de Ciências.

Sigel EM. 2016. Genetic and genomic aspects of hybridization in ferns. 2016. Journal of Systematics and Evolution 54: 638-755.

Smith AR, Pryer KM, Schuettpelz E, Korall P, Schneider H, Wolf PG. 2006. A classsification for extant ferns. Taxon 55: 705-731.

Sousa HCF, Gonçalves-Esteves V, Mendonça CBF. 2017. Pollen diversity in selected species of the tribe Chironieae (Gentianaceae Juss.) that occur in the Atlantic Forest, Brazil. Acta Botanica Brasilica 31: 120-127.

Souza MA, Mendonça CBF, Esteves R, Gonçalves-Esteves V. 2016. Pollen morphology of species of Graphistylis B. Nord. (Asteraceae) of Brazil. Acta Botanica Brasilica 30: 138-146.

Sylvestre LS. 1995. Palinologia das Polypodiaceae sensu lato do Planalto de Itatiaia, Rio de Janeiro, Brasil. Arquivos do Jardim Botânico do Rio de Janeiro 33: 9-73.

Thiers B. [continuously updated] 2018. Index Herbariorum: a global directory of public herbaria and associated staff. New York, New York Botanical Garden's Virtual Herbarium. http://sweetgum.nybg. org/ih. 15 Jun. 2018.

Tryon AF, Lugardon B. 1990. Spores of the Pteridophyta: surface, wall structure, and diversity based on electron microscope studies. New York, Springer-Verlag.

Tryon RM, Tryon AF. 1982. Ferns and allied plants - with special reference to Tropical America. New York, Springer-Verlag.

Wanderley MGL, Melhem TS. 1991. Flora polínica da reserva do Parque Estadual das Fontes do Ipiranga (São Paulo, Brasil). Família: 178 Bromeliaceae. Hoehnea 18: 5-42.

Wodehouse RP. 1935. Pollen grains. Their structure, identification and significance in science and medicine. New York, McGraw-Hill Book Company. 